\title{
The Effect of Blended Learning on Student's Learning Achievement and Science Process Skills in Plant Tissue Culture Course
}

\section{Fauziyah Harahap}

Dr., correspondence author, Biology Department, Universitas Negeri Medan, Indonesia,fauziyahharahap@unimed.ac.id

\section{Nanda Eska Anugrah Nasution}

M.Pd., Biology Education Department, Universitas Negeri Medan, Indonesia, nsteska@gmail.com

\section{Binari Manurung}

Prof. Dr. rer. nat., Biology Department, Universitas Negeri Medan, Indonesia, binarimanurung@unimed.ac.id

The purpose of this research was to know the effect of blended learning strategy on learning achievement and science process skills of students in plant tissue culture course in the Universitas Negeri Medan. The research method was quasi experiment. The population of this study was all semester VIII students of biology education program. The study sample consists of two classes, namely: class A known as control class who were taught by conventional learning strategy and class $\mathrm{C}$ known as experiment class who were taught by blended learning strategy. They were selected using cluster random sampling technique. The results of the study showed that tcount $=3.769, \mathrm{P}=0.001$ at the level significance of 0.05 in learning achievements score. It also showed that tcount $=5.435>$ ttable $=1.661 \mathrm{P}=0.001$ at the level significance of 0.05 in science process skills score. Based on the study result, it can be concluded the blended learning strategy found significantly more effective in enhancing students' learning achievement and science process skills in plant tissue culture course as compared to the conventional learning strategy.

Keywords: blended learning, plant tissue culture, sciences process skills, learning achievement, learning achievement

\section{INTRODUCTION}

Plant tissue culture is branch of biological science. Also, it is one of the compulsory courses in biology program of the Universitas Negeri Medan . Students must pass this course in order to meet the eligibility criteria to graduate. Based on researcher

Citation: Harahap, F., Nasution, N. E. A., \& Manurung, B. (2019). The Effect of Blended Learning on Student's Learning Achievement and Science Process Skills in Plant Tissue Culture Course. International Journal of Instruction, 12(1), 521-538. https://doi.org/10.29333/iji.2019.12134a 
experiences as a plant tissue culture lecturer for over ten years and students learning achievement during these years, a lot of students have learning difficulties in plant tissue culture course, as many students pass this course with poor final scores. According to Batubara (2016), students have difficulties in learning plant tissue culture course in university due to lack of learning aid in understanding the course optimally. This research aims to understand the learning difficulties of students and in improving their learning achievement. Plant tissue culture course as a science-based course makes good science to process skills that are needed for every student to improve his learning achievement in this course. Creating a learning environment that concerns the science process skills of students is one of the lecturer's responsibilities. This responsibility is separate from improving the learning achievement of students of the course.

The use of technology such as the internet in improving the education achievement has increased rapidly. Internet usage, nowadays, unavoidably must be integrated into higher education system. It offers learning by reading, watching, hearing, communicating, discussing, and writing/typing opportunity.

The common implementation of Internet in teaching and learning environment is known as e-learning. While e-learning involves the use of Internet technologies to enhance knowledge and performance (Jethro et al., 2012).

Blended learning is a strategy that combines traditional classroom teaching and an elearning system (Zou, 2005). Consequently, blended learning aims at combining the advantages of both face-to-face and e-learning environments (Ghahari, 2013). Hopper (2003) stated that blended courses have proven to be more effective than fully online courses because blended learning can create a positive relationship between face-to-face and online environments. Blended learning develops students as independent learners (Snodin, 2013).

Blended learning has the capability to improve science process skills and the learning achievement of students in plant tissue culture course. This is because it provides a lot of learning aids like: images, animations, videos, texts, pictures, chat room, etc. In addition, it creates an interaction among students. Finally, it supports constructive and the social learning experiences of students. It also has a wide scope for extending immense opportunity for children to ask questions, describe objects and events, acquire knowledge, construct explanations of natural phenomena, test those explanations in many different ways and communicate their ideas to others; thus, all of these are critical elements of learning science course (Krishnan, 2015).

A typical example of blended learning methodology is the combination of technologybased materials and face-to-face sessions in presenting content (Coswie \& Nichols, 2010). So, blended learning offers students the flexibility of place, time, media, and pace to learn without ignoring the social needs for student to collaborates, interacts, engage in critical debates, and communicate with other students and lecturers. 


\section{Theoretical Background}

\section{Blended learning}

The meaning of blended learning has been interpreted by some experts using many definitions. Horton (2002) and Osguthorpe (2003) define blended learning as the combination of the strong and advantageous aspects of web-based learning with those of face-to-face learning. Blended learning also described as a mode of teaching that eliminates time, place, and situational barriers, whilst enabling high quality interactions between teachers and students (Kanuka \& Rourke, 2014).

Computer, internet and its associated technologies are considered as the main ICTs and basics to rest of such technologies. Seemingly, ICTs have become popular and are used to facilitate and enhance communication and interactions among the users (Hussain, 2018). Blended learning forces us to consider the characteristics of digital technology, in general, and information communication technologies (ICTs), more specifically (Dziuban, 2018). Aspects of blended e-lerning such as: web-based instruction, streaming video, audio, synchronous and asychronous communication, etc: with tradisional, faceto-face"learning (Ahmed, et.al., 2008).

In this study, the implementation of online learning applied is web-based instruction, and classroom learning with face-to-face learning. Wijaya (2012) says, website-based learning (e-learning) is a learning process carried out through a network. This learning allows teaching materials to arrive at students, using information and communication technology media, in the form of computers and internet or intranet networks. Munir (2009) defines website-based learning (e-learning) as information technology, which is applied in the field of education, in the form of virtual world. The term website-based learning (e-learning) is more appropriate is an attempt to make a transformation of the learning process that exists in schools or colleges into digital forms through internet technology.

The usage of blended learning in learning and teaching has become a popular approach in higher education, Kintu et al. (2017) stated that the introduction of blended learning initiatives is part of these innovations but its uptake, especially in the developing world faces challenges for it to be an effective innovation in teaching and learning.

As mentioned before, blended learning benefits for students and lecturers. Poon (2013) said blended learning facilitates improved learning outcomes, access flexibility, a sense of community, the effective use of resources, and student satisfaction. Some studies conclude that designing a blended course improves students' academic achievement and that the students also showed positive attitude towards the implementation of blended learning (Boyle, 2003; Francis, 2013; Dziuban, 2004; Maguire, 2005; Simpson \& Anderson, 2009; Garnham \& Kaleta, 2002; Lim \& Morris, 2009; O'Toole \& Absalom, 2003; Twigg, 2003). Other studies also stated that blended learning enhance science process skills and learning achievement rather than conventional method (Krishnan, 2015; Bayrak \& Bayram, 2009; Tan, Yeo \& Lim, 2005). 
Based on the description above, and the elements that must be in Blended Learning. We can understand that many learning theories underlie this Blended Learning. Namely the theory of learning Constructivism (individual learning), from Piaget. Knowledge is human thought. Humans construct their knowledge through interaction with objects, phenomena, experiences and their environment. Knowledge cannot be transferred from someone to another without understanding the context (Suparno, 1997). (Dahar, 1989) asserts that knowledge is built in the child's mind, not acquired passively by someone. Piaget (Suparno, 1997) says that, knowledge is basically adaptation into a reality, as an organism adapts to its environment. Adaptation according to Piaget is a balance between assimilation and accommodation. Assimilation is the absorption of new information into the mind, while accommodation is rearranging the structure of the mind because of new information, so that information has a place (Ruseffendi, 1991). E-learning strongly supports the process of assimilation and accommodation simultaneously during learning. The assimilation occurs when students absorb Plant Tissue Culture material when doing e-learning, anytime and anywhere through the website, and accommodation goes naturally when students learn according to the optimum conditions of students. Cognotive theories from Bruner, Gagne and Blooms that sharpen individually students cognitive abilities, when learning independently through the website, as well as during classical learning, and social constructivisit (collaborativ learning) from Vygotsky. This can be seen during classical learning, group work, discussion, expressing opinions in class.

\section{Plant Tissue Culture Course}

Plant Tissue Culture Course is one of the compulsory subjects in the Biology Education Departement at Universitas Negeri Medan. Content courses was published in Wibe site. Content Courses that must be achieved by students are (1) An introduction of tissue culture plant: cell theory of totipotency, it's benefits, needs and implementation, science the underlying plant tissue culture, aseptic techniques, (2) Plant tissue cultures medium and it's components (3) Composing plant tissue culture medium., (4) In vitro plant propagation: protoplast culture and protoplast fusion, (5) In vitro plant propagation : cell and callus culture, (6) Organogenesis : apical culture, meristem culture, embryogenesis, embryo culture, and root culture.

\section{Learning Achievement}

Learning Achievement is a product of the learning process (Lizzio et al., 2002) achieved by the students after the students follow a particular teaching unit. Sudjana (2006) said that the success of a student in achieving the objective of learning can be seen from his learning scores. Cognitive is one of learning achievment domain identified by an expert named Benjamin Bloom, the cognitive domain involves knowledge and the development of intellectual skills. Cognitive outcomes refer to the development of knowledge and professional skills while non-cognitive outcomes focus on changing the attitudes and values of individuals (Ewell, 1985). This includes the recall or recognition of specific facts, procedural patterns, and concepts that serve in the development of intellectual abilities and skills. There are six major categories of learning achievment revised by 
Anderson (2001) based on "Bloom's Taxonomy", they are : Remember (C1), Understand (C2), Apply (C3), Analyze (C4), Evaluate (C5), and Create (C6).

\section{Science Process Skills}

The aim of plant tissue culture as one of science course is to enable students to apply scientific process skills in learning process; Students achieve the science process skills if they may be able to do all the science process skill's indicator based on Rustaman (2005); Dimyati and Mujiono (2009), such as to observe, to classify, to interpret, to predicting, to ask question of a problems, to make a hypothesis, to plan an experiment, to implement concept, and to communicate result. These skills can be gained by students through certain science education activities (Huppert, et al, 2010, Harlen, 1999). Science process skills can develop the ability to observe, classify, assess or interpret, predict, research plans, communicate (Sumantri et al, 2001 ; Hamalik, 2008 ; Usman, 2008)

Raj and Devi (2014) said that science process skills are defined as transferable skills that are applicable to many sciences and that reflect the behaviors of scientists. They are the skills that facilitate learning in physical sciences, ensure active student participation, have students develop the sense of undertaking responsibility in their own learning, increase the permanence of learning, and also have students acquire research ways and methods, that is, they ensure thinking and behaving like a scientist. Science Process Skills are essential for teaching science content knowledge and scientific inquiry because lecturers who have a poor understanding of the science process skills are less likely to have a positive attitude towards them and are, therefore, less likely to teach them to their students (Cain, 2002).

\section{Purposes of the study}

The purposes of this study where (1) to find out is there any effect of using blended learning strategy on student's science process skills at plant tissue culture course in Universitas Negeri Medan. (2) to find out is there any effect of using blended learning strategy on student's learning achievement at plant tissue culture course in Universitas Negeri Medan.

\section{METHOD}

\section{Research Design}

This study used a cluster random sampling technique of 94 students from two intact classes of Biology Program in Faculty of Mathematics and Science at the Universitas Negeri Medan, Indonesia. One class of 51 students acted as the experimental class, and another class of 43 students acted as the control class. Both classes were taught by the researcher. The two class were pretested on the achievement test before the treatment. The results of a t-test showed that there were no statistically significant differences both on pre-test scores of learning cognitive ability $\left(\mathrm{t}_{\text {count }}(0.65) ; \mathrm{P}=0.516\right)$ between the experimental class and the control class and pre-test scores of sciences process skills ( $\left.\mathrm{t}_{\text {count }}(0.0925) ; \mathrm{P}=0.919\right)$. Therefore, these results indicate that students in both the experimental and control classes had similar pretest scores in learning cognitive ability 
and sciences process skills in plant tissue culture subject before the experiment commenced. To determine the effect of blended learning on students' learning achievement and science process skills, pre and post-tests before and after the implementation of blended learning in the course were applied.

Before the implementation, the researcher has designed a special education website to teach the basic concept of the course contents in plant tissue culture. The website used as learning media for this study in blended learning class was developed using Hypertext Markup Language (HTML), Hypertext Preprocessor (PHP), and JavaScript language.The website course contents and design were revised by taking the validation of: 2 lecturers who are experts on plant tissue culture material and language, 2 lecturers who are experts on learning media design, 2 lecturers who are experts in instructional design, and 2 lecturers who are experts on website design. After that, the website was revised by taking the opinion of 3 students that passed plant tissue culture class. After that, it was revised by taking the opinion of 10 students that passed plant tissue culture class. Lastly, it was revised by taking the opinion of 30 students that passed plant tissue culture class. Students were informed about the practice. The final result of the design of this plant tissue culture website declared valid and feasible. the effectiveness test can be carried out (Nasution, 2017).

Scope this research is an advanced research, to implement it by testing its effectiveness in tissue culture courses through Blended Learning. The research method is quasiexperimental. Using two classes, one class as the control class and another class acted as the experimental class.

Table 1

Research design in blendded learning

\begin{tabular}{lccc}
\hline \multicolumn{1}{c}{ Group } & Pretest & Treatment & Posttest \\
\hline experiment class & $\mathrm{Pa}_{1} \mathrm{~Pb}_{1}$ & $\mathrm{X} 1$ & $\mathrm{~Pa}_{2} \mathrm{~Pb}_{2}$ \\
\hline control class & $\mathrm{Pa}_{1} \mathrm{~Pb}_{1}$ & $\mathrm{X} 2$ & $\mathrm{~Pa}_{2} \mathrm{~Pb}_{2}$ \\
\hline
\end{tabular}

\section{Deskriptor :}

$\mathrm{X} 1 \quad$ : Learning with blended learning

X2 : Learning with conventional learning

$\mathrm{Pa}_{1} \quad$ : Pretest (Learning Achievement, Kognitif C1-C6)

$\mathrm{Pa}_{2} \quad$ : Postest (Learning Achievement, Kognitif C1-C6)

$\mathrm{Pb}_{1} \quad$ : Pretest (Science Process Skills)

$\mathrm{Pb}_{2} \quad$ : Postest (Science Process Skills

The learning achievement test and science process skills test prepared within the scope of the study were applied as a pretest to the students. The practice took five weeks (10 class hours). The control class studied in a class where conventional learning (lecture and discussion) using graphic media such as Power point, book and animation was offered. On the other hand, the experimental class studied in a class where blended 
learning environment (lecture and discussion) using website as learning media has been provided by using rotation model. At the end of the practice, the science process skills test and the achievement test was applied as a post-test to the students.

\section{Data Collection Tools and Data Collection}

\section{Science Process Skills Test}

The science process skills test which consist of 18 items that tests basic and integrated science process skills was based on the relevant literature (Rustaman, 2005). This test also covered all knowledge aspects of six plant tissue culture undergraduate learning objectives. Table 2 shows the distribution of respective science process skills instrument test and the indicator based on the study of Rustaman (2005).

Table 2

Distribution of science process skills instrument test items

\begin{tabular}{clll}
\hline No & Indicator of science process skills & Item's number & Total \\
\hline 1 & Observing & 6,4 & 2 \\
\hline 2 & Classify & 3,13 & 2 \\
\hline 3 & Interpret & 7,3 & 2 \\
\hline 4 & Predicting & 8,9 & 2 \\
\hline 5 & Asking question & 4,15 & 2 \\
\hline 6 & Making hypothesis & 10,16 & 2 \\
\hline 7 & Planning an experiment & 5,17 & 2 \\
\hline 8 & Implementing concept & 11,18 & 2 \\
\hline 9 & Communicating result & 1,12 & 2 \\
\hline
\end{tabular}

With the fear that students might get their answers correct just by luck if the questions used in this science process skills test were multiple choice ones, the researcher decided to use essay test. The researcher made an assesment rubric for every possible answer for each items. Thus, the students got score zero (0) if the answer is wrong, one (1) if a little part of the answers is correct, 2 (two) if the answer is half/partially correct, three (3) if the answers is almost completely correct, and four (4) if the answer is perfectly correct. The maximum score for the science process skills test was 100. The content and face validity of this test was confirmed and checked through the revision and comments of 5 doctorate and master's degree holders and lecturers in plant tissue culture education at the Universitas Negeri Medan . Furthermore, the test was piloted with biology students $(n=20)$ who had taken the plant tissue culture course the semester before. Using product moment correlation, 18 items of science process skills was valid $\left(\mathrm{r}_{\text {count }}>0.44\right)$. Using Crobach's Alpha, the reliability of science process skills test was 0.941. It was, therefore, accepted that the test was valid and had good reliability and discriminatory power.

\section{Learning Achievement Test}

Learning Achievement test which included 30 items was developed in order to collect quantitative data. This test covered all knowledge aspects of six plant tissue culture undergraduate learning objectives with variation of cognitive levels. These levels 
include C1- C6 adopted from Bloom's cognitive taxonomy revised by Anderson (2001). The distribution of instrument test is displayed in Table 3.

Table 3

Distribution of learning achievement instrument test cognitive level

\begin{tabular}{|c|c|c|c|c|c|c|}
\hline \multirow{2}{*}{ Subject Aspects } & \multicolumn{6}{|c|}{ Cognitive Level } \\
\hline & C1 & $\mathrm{C} 2$ & $\mathrm{C} 3$ & $\mathrm{C} 4$ & C5 & C6 \\
\hline $\begin{array}{l}\text { An introduction of plant tissue culture: cell theory of } \\
\text { totipotency, it's benefits, needs and implementation. }\end{array}$ & & 1 & 5 & & & \\
\hline Plant tissue cultures medium and it's components. & & 13 & 3 & 11 & 12 & 14 \\
\hline Composing plant tissue culture medium. & 9 & 7 & 16 & 10 & 8,4 & 15,2 \\
\hline $\begin{array}{l}\text { In vitro plant propagation: protoplast fusion and } \\
\text { callus culture. }\end{array}$ & 24 & 27 & 18 & & 21 & 6 \\
\hline In vitro plant propagation : cell and callus culture. & 25 & & 26 & 23 & 28 & \\
\hline $\begin{array}{l}\text { Organogenesis : apical culture, meristem culture, } \\
\text { embryogenesis, embryo culture, and root culture. }\end{array}$ & 22 & 43 & $\begin{array}{l}19 \\
29\end{array}$ & & 20 & 17 \\
\hline
\end{tabular}

Note:

$$
\begin{array}{lll}
\text { C1 } 1=\text { Remembering } & \text { C3 }=\text { Applying } & \text { C5 }=\text { Evaluating } \\
\text { C2 }=\text { Understanding } & \text { C4 }=\text { Analyzing } & \text { C6 }=\text { Creating }
\end{array}
$$

As many as 19 questions at C1-C4 cognitive level were presented in multiple-choice format, while the other 11 questions at C5-C6 cognitive level were presented in essay format. For multiple-choice format, each item had five alternative choices for the correct answer, for each question, the students get score one (1) if the answer is correct and zero (0) if the answer is wrong. For essay format, students gets score zero (0) if the answer is completely wrong or unanswered, one (1) if the answer is almost complete and correct, and two (2) if the answer is complete and correct. The maximum score for the knowledge component of the achievement test was 100 . The content and face validity of this test was confirmed and checked through revision and comments of 5 doctorate and master's degree holders and lecturers in plant tissue culture education at the Universitas Negeri Medan. The test was piloted with biology students $(n=20)$ who had taken the plant tissue culture course the semester before. Using product moment correlation showed that 30 out of 45 items of learning achievement test was valid $\left(r_{\text {count }}>0.44\right)$. Using Crobach's Alpha, the reliability of learning achievement test was 0.953. It was, therefore, accepted that the test was valid and had good reliability and discriminatory power.

\section{Statistical Analysis}

All statistical analyses were calculated using SPSS statistical package software. Normality test performed by using liliefors test. Hypothesis testing is done by t-test (Arikunto, 2010):

$$
t=\frac{\bar{X}_{1} \bar{X}_{2}}{s \sqrt{\frac{1}{n_{1}}+\frac{1}{n_{2}}}}
$$

$\bar{X}_{1}=$ Mean of learning achievement or science process skills in the blended learning class 
$\bar{X}_{1}=$ Mean of learning achievement or science process skills in the conventional class

$\mathrm{n}_{1} \quad=$ Number of students on blended learning class

$\mathrm{n}_{2} \quad=$ Number of students on conventional class

$\mathrm{S} \quad=$ standard deviation, both classes

Comparing $\mathrm{t}$ count with $\mathrm{t}$ table, $\alpha=0.05$ and $\mathrm{df}$ (degree of freedom) $=\mathrm{n} 1+\mathrm{n} 2-2$. If $\mathrm{t}$ count $\langle t$ table then $\mathrm{H} 0$ will be accepted and $\mathrm{Ha}$ is rejected. If $\mathrm{t}$ count $>\mathrm{t}$ table then $\mathrm{H} 0$ will be rejected and $\mathrm{Ha}$ accepted.

\section{FINDINGS}

Table 4

Normality test result

\begin{tabular}{llllll}
\hline Research Class & & & Lcount & Ltable & Conclusion \\
\hline Control Class & learning achievement & Pretest & 0.12 & 0.135 & Normal \\
\cline { 2 - 6 } & & Posttest & 0.1 & 0.135 & Normal \\
\cline { 2 - 5 } & \multirow{2}{*}{ science process skills } & Pretest & 0.1 & 0.135 & Normal \\
\cline { 3 - 5 } & & Posttest & 0.1 & 0.135 & Normal \\
\hline \multirow{2}{*}{$\begin{array}{l}\text { Experimental } \\
\text { class }\end{array}$} & learning achievement & Pretest & 0.09 & 0.124 & Normal \\
\cline { 2 - 5 } & & Posttest & 0.11 & 0.124 & Normal \\
\cline { 2 - 5 } & science process skills & Pretest & 0.12 & 0.124 & Normal \\
\cline { 2 - 5 } & & Posttest & 0.12 & 0.124 & Normal \\
\hline
\end{tabular}

As displayed in Table 4, the normality test performed by using liliefors test and the results shows that all data are distributed normally.

Table 5

Mean and standard deviations of science process skills post-test scores

\begin{tabular}{llll}
\hline Class & $\mathrm{N}$ & Mean & Std. Deviation \\
\hline Experimental class & 51 & 79.93 & 11.82 \\
Control Class & 43 & 70.15 & 9.86 \\
\hline
\end{tabular}

As displayed in Table 5, the students in experimental class who were taught with blended learning strategy had a higher science process skills post-test score $(\bar{X}=79.93$, $\mathrm{SD}=11.82)$ than students in control class who were taught by conventional learning strategy $(\overline{\mathrm{X}}=70.15, \mathrm{SD}=9.86)$. To answer the research question "Is there any effect of using blended learning strategy on student science process skills at plant tissue culture course in Universitas Negeri Medan ?", We calculated the post-test score of both class by using t-test as displayed in Table 5 . 
Table 6

The independent sample t-test result of science process skills posttest

\begin{tabular}{|c|c|c|c|c|c|c|}
\hline \multirow{2}{*}{ Class } & \multicolumn{2}{|c|}{$\begin{array}{l}\text { Levene's Test for } \\
\text { Equality of Variances }\end{array}$} & \multicolumn{4}{|l|}{ t-test } \\
\hline & $\mathrm{F}$ & Sig. & $\mathrm{t}$ & Df & $\begin{array}{l}\text { Sig }(2 \\
\text { tailed }) .\end{array}$ & $\begin{array}{l}\text { Mean } \\
\text { Differences }\end{array}$ \\
\hline $\begin{array}{l}\text { Equal variances assumed } \\
\text { Equal variances not assumed }\end{array}$ & 7.854 & .006 & $\begin{array}{l}-4.303 \\
-4.370\end{array}$ & $\begin{array}{l}92 \\
91.993\end{array}$ & $\begin{array}{l}.000 \\
.000\end{array}$ & $\begin{array}{l}-9.77446 \\
-9.77446\end{array}$ \\
\hline
\end{tabular}

As shown in Table 6 , the obtained $\mathrm{p}(0.000)$ is smaller than 0.01 . Thus, the test is significant at 0.01 level. This means that there is a significant difference of science process skills between the two classes. This result indicates that there is an effect of using blended learning strategy on student's science process skills at plant tissue culture course in the Universitas Negeri Medan .

Table 7

Mean and independent sample t-test result for each indicators between both classes in science process skills posttest

\begin{tabular}{llll}
\hline \multicolumn{1}{c}{ Indicators } & Control Class & Experiment Class & Sig \\
\hline Observing & 60.47 & 76.23 & $0.001^{* *}$ \\
\hline Classify & 86.92 & 95.59 & $0.013^{*}$ \\
\hline Interpret & 48.55 & 68.63 & $0.00 * *$ \\
\hline Predicting & 55.52 & 71.08 & $0.00^{* *}$ \\
\hline Asking question & 53.78 & 60.78 & 0.305 \\
\hline Making hypothesis & 86.34 & 93.14 & $0.048^{*}$ \\
\hline Planning an experiment & 75.29 & 77.21 & 0.599 \\
\hline Implementing concept & 87.21 & 89.22 & 0.58 \\
\hline Communicating result & 77.33 & 87.50 & $0.00 * *$ \\
\hline \multicolumn{1}{c}{ Mean } & 70.15 & 79.93 & $0.00 * *$
\end{tabular}

As shown in Table 7, almost all result of science process skills posttest in all indicators showed significant differences among students in control and experiment classes except for asking questions, planning an experiment, and implementing concept. Indicators that has a significant differences among both classes at level 0.05 are : classify and making hypothesis. And indicators that has a significant differences among both classes at level of 0.01 are : observing, interpret, predict, ad communicating result.

Table 8

Mean and standard deviations of learning achievement post-test scores for two class

\begin{tabular}{llll}
\hline Class & $\mathrm{N}$ & Mean & Std. Deviation \\
\hline Experimental class & 51 & 85.75 & 6.76 \\
Control Class & 43 & 80.08 & 7.81 \\
\hline
\end{tabular}

As displayed in Table 8, the students in the experimental class who taught with blended learning strategy had a higher learning achievement post-test score $(\overline{\mathrm{X}}=85.75, \mathrm{SD}=6.76)$ than students in the control class who were taught by conventional learning strategy $(\bar{X}=80.08, \mathrm{SD}=7.81)$. To answer the research question "Is there any effect of using blended learning strategy on student Learning Achievement at plant tissue culture course 
in Universitas Negeri Medan ?", we calculated the post-test score of both class by using t-test as displayed in Table 9.

Table 9

The independent sample t-test result of Learning Achievement posttest

\begin{tabular}{|c|c|c|c|c|c|c|}
\hline \multirow{2}{*}{ Class } & \multicolumn{2}{|c|}{$\begin{array}{l}\text { Levene's Test for } \\
\text { Equality of Variances }\end{array}$} & \multicolumn{4}{|l|}{ t-test } \\
\hline & $\mathrm{F}$ & Sig. & $\mathrm{t}$ & Df & $\begin{array}{l}\text { Sig }(2 \\
\text { tailed). }\end{array}$ & $\begin{array}{l}\text { Mean } \\
\text { Differences }\end{array}$ \\
\hline $\begin{array}{l}\text { Equal variances assumed } \\
\text { Equal variances not assumed }\end{array}$ & .478 & .491 & $\begin{array}{l}-3.772 \\
-3.726 \\
\end{array}$ & $\begin{array}{l}92 \\
83.765\end{array}$ & $\begin{array}{l}.000 \\
.000\end{array}$ & $\begin{array}{l}-5.67416 \\
-5.67416 \\
\end{array}$ \\
\hline
\end{tabular}

As shown in Table 9, the obtained $\mathrm{p}(0.000)$ is smaller than 0.01 . So the test is significant at 0.01 level. This means that there is a significant difference between the two classes. This result indicates that there is an effect of using blended learning strategy on student learning achievement at plant tissue culture course in the Universitas Negeri Medan .

Table 10

Mean and independent sample t-test result for each cognitive level between both classes in Learning Achievement posttest

\begin{tabular}{llll}
\hline \multicolumn{1}{c}{ Cognitive Level } & Control Class & Experiment Class & Sig \\
\hline C1 (remembering) & 77.32 & 85.2 & $0.05^{*}$ \\
\hline C2 (understanding) & 87.91 & 91.37 & 0.138 \\
\hline C3 (applying) & 79.4 & 86.55 & $0.008^{* *}$ \\
\hline C4 (analyzing) & 77.52 & 85.62 & 0.078 \\
\hline C5 (evaluating) & 80.23 & 85.95 & $0.042^{*}$ \\
\hline C6 (creating) & 76.74 & 79.2 & 0.48 \\
\hline Mean & 80.08 & 85.75 & $0.00 * *$ \\
\hline
\end{tabular}

As shown in Table 10, the following cognitive levels showed significant differences among students in control and experiment classes at level 0.05, they are : $\mathrm{C} 1$ (remembering) and C5 (evaluating). Cognitive level that has a significant differences among both classes at level 0.01 is : C3 (applying). And cognitive levels that has no significance differences between both classes are : C2 (understanding), C4 (analyzing), and C6 (creating).

\section{DISCUSSION}

According to the result that showed there is an effect of using blended learning strategy on student's science process skills at plant tissue culture course in the Universitas Negeri Medan, it can be inferred that the teaching plant tissue culture using blended learning strategy does have a positive impact on the sciences process skills test score in Biology program in the Universitas Negeri Medan. The result is in agreement with that of Krishnan (2015) which states that blended learning is more effective than conventional method in enhancing science process skills. This research is also similar with that of Saat (2004) who discovered that a web-based learning environment helps students to acquire science process skills. By blended learning, the ability of the science process is formed by students themselves through independent learning process. 
Therefore, students are required to understand the subject independently and in depth. By blended learning, the students are also required to learn the subject individually before entering the class, although then it will be discussed together in the class. It is the individual learning that is likely to be one of the reasons why blended learning can improve students' science process skills. Students personally build their understanding of material content by following the steps of science learning such as observation, classification, and prediction. Students are also assisted by multimedia provided by lecturers on the website, such as in videos, animations, pictures, games, and flash. Lecturers also provide virtual assignment of problems about plant tissue culture through the website. Also, students are required to be able to find a way out of the problem and expose it online in the discussion forums on the website. Through the availability of the virtual task, students are required to actively carry out science activities such as interpretation, prediction, making hypotheses, asking questions, applying concepts, planning research, and communicating research results. Therefore, with so many learning aids and scientific discussion between students and lecturers, students are able to improve their science process skills.

According to the second result that indicates that there is an effect of using blended learning strategy on student learning achievement at plant tissue culture course in the Universitas Negeri Medan, it can be inferred that the teaching plant tissue culture using blended learning strategy does have a positve impact on the learning achievement test score in Biology program in Universitas Negeri Medan. The result of this research supports the research findings of Obiedat et al (2014) which states that there is a significant and positive impact of blended learning on academic achievement of the students in the University of Jordan. The result of this research, that blended learning environment improves the learning achievement averages of students, also supports findings by Abidoye (2015), Kazu and Mehmet (2014), Ismail et al (2014), Means et al. (2013), Dziuban et al. (2011), and Korkmaz and Karakus (2009). Sridevi (2008) and Krishnan (2015), in their research, found that the improvement of science process skills is related with the learning achievement of students. Garrison and Kanuta (2004) remarked that blended learning has the power to promote deep learning. According to Simpson \& Anderson, (2009), the advantages of blended learning have been backing its central position in higher education. Kenney and Newcombe (2011) also did their comparison to establish effectiveness in view of grades and found that blended learning had higher average score than the non blended learning environment.

Nasution et al (2016) summarized that there is an effect of using blended learning approach on student critical thinking skills in plant tissue culture course when compared with conventional learning approach. Alzahranil and O'Toole (2017), said students in the present study supported the implementation of blended learning, but not entirely online learning. Blended learningis suitable to be used by the students of Biology Education (Desy and Setyoko, 2017)

It can be concluded that the reasons for the improvement of science process skills of students can be applied to similar results in science achievement. Blended learning provides students access to multiple media and learning aids under the guidance and the 
control of lecturers. It also offers a flexible learning time for students in some subject. As a result, the students can manage their own learning time based on their avaibility and learning styles. The forum and discussion room in learning website provide students places to ask questions and provide answers, engage in critical debate, and discuss the learning material. All of these improved the students learning cognitive ability, and finally the learning achievement.

\section{CONCLUSION}

The result of this study is in line with many previous studies. There is an effect of using blended learning strategy on student science process skills. It can be concluded that the blended learning strategy is significantly more effective in enhancing student's science process skills in plant tissue culture course in Universitas Negeri Medan when compared with conventional learning strategy. In addition, there is an effect of using blended learning strategy on student learning achievement. It can also be concluded that the blended learning strategy is significantly more effective in enhancing student's learning achievements in plant tissue culture course in Universitas Negeri Medan when compared with conventional learning strategy.

Both results show that blended learning has a positive effect on students in learning plant tissue culture course at higher education. Students in higher university, especially in this study, are young adults (18-23 years old) who have been able to manage their own learning time and style. They have a high self discipline and good motivation to spend a lot of their time outside of the class learning this course individually or cooperatively on the website provided in this blended learning.

As mentioned before, the website used as learning media for this study in blended learning class was developed using HTML, PHP, and JavaScript language. By developing a website on researcher's own allows researcher creates a learning media based on student's character, learning ability and learning style. Therefore, researcher suggest for lecturers who want to use blended learning as learning strategy in higher education, especially on plant tissue culture course, to study and understands the student's character, learning ability and learning style on that course, then develop the website based on these student's criteria. 


\section{REFERENCES}

Abidoye, J. A. (2015). The Effect of Blended Learning Instructional Approach on Secondary School Students Academic Achievement in Geography in Akure, Ondo State, Nigeria. Research Journal of Educational Studies and Review. 1(5), pp. 106-110.

Alzahrani1, M.G. and O'Toole, J.M. (2017). The Impact of Internet Experience and Attitude on Student Preference for Blended Learning. Journal of Curriculum and Teaching, 6(1), 65-78

Anderson, L.W. Krathwohl, D.R., Airasian, P.W., Cruikshank, K.A., Mayer, R.E., Pintrich, P.R., Raths, J., Wittrock, M.C. (2001). A Taxonomy for Learning, Teaching, and Assessing: A revision of Bloom's Taxonomy of Educational Objectives. New York: Pearson, Allyn \& Bacon.

Arikunto, S. (2010). Prosedur Penelitian. Jakarta: Rineka Cipta.

Batubara, M. S. Pengembangan Video Pembelajaran Mata Kuliah Kultur Jaringan Berbasis Masalah, Masters thesis, UNIMED, 2016.

Bayrak, K. B. \& Bayram, H. (2009). The effect of web based learning method in science education on improving the students' scientific process skills. Paper presented at the International Conference: The Future of Education.

Boyle, T., Bradley, C., Chalk, P., Jones, R., \& Pickard, P. (2003). Using blended learning to improve student success rates in learning to program. Journal of Educational Media, 28. 2-3, 165-178.

Cain, S (2002). Sciencing. (4th ed). Upper Saddle River, NJ: Pearson Education.

Coswie P. \& M. Nichols. (2010). The clash of cultures: Hybrid learning course development as management of tension. Journal of Distance Education 24(1).77-90.

Dahar, R.W. 1989. Teori-Teori Belajar. Jakarta: Erlangga.

Desy, R., Setyoko, S. (2017) Pengembangan Pembelajaran Blended Learning Berbasis Website Di Program Studi Pendidikan Biologi Universitas Samudra. Jurnal Pendidikan Biologi, 6/3, 346-350

Dimyati and Mujiono., (2009). Belajar dan Pembelajaran, Jakarta: PT Rineka Cipta

Dziuban, C. D., Hartman, J. L., \& Moskal, P. D. (2004). Blended Learning. Internet, 7 , $1-44$.

Dziuban, C., Joel, H., Thomas, B., Cavanagh. and Patsy, D. M. (2011). "Blended Courses as Drivers of Institutional Transformation." In Blended Learning Across Disciplines: Models for Implementation, edited by A. Kitchenham, 17-37. Hershey, PA: Information Science Reference. 
Dziuban, C., Graham, C. R., Moskal, P. D., Norberg, A., \& Sicilia, N. (2018). Blended Learning: The New Normal And Emerging Technologies. International Journal of Educational Technology in Higher Education, 15(3), 1-16

Ewell, P. T. (1985). Assessing educational outcomes. New directions for institutional research, San Francisco: Jossey-Bass.

Francis, R. \& Susan, J. S. (2013). Engaging with blended learning to improve students' learning outcomes. European Journal of Engineering Education. 4, 359-369

Garnham, C. \& Kaleta, R. (2002). Introduction to hybrid courses. Teaching with Technology Today, 8(6)

Garrison, R. \& Kanuka, H. (2004). Blended learning: Uncovering its transformative potential in higher education. Internet and Higher Education, 7, 95-105.

Ghahari, S. (2013). The Effect of Blended Learning vs. Classroom Learning Techniques on Iranian EFL Learners' Writing. International Journal of Foreign Language Teaching \& Research. Vol.1/3 Spring 2013.

Hamalik, O. (2008). Kurikulum dan Pembelajaran. Jakarta : PT Bumi Aksara.

Harlen, W. (1999). Purposes and procedures for assessing science process skills. Assessment in Education, 6(1), 129-140.

Hopper, K. (2003). Reasons to go hybrid. Distance Education Report, 7(24), 7.

Horton, W. (2002). Designing web-based training. NY: Wiley.

Huppert, J. S. Michal Lomask \& R. Lazarowitz (2010). Computer simulations in the high school: students' cognitive stages, science process skills and academic achievement in microbiology. International Journal of Science Education, 24/8, 803-821.

Hussain, I., Cakir, O., Candeğer, Ü. (2018). Social Media as a Learning Technology for University Students. International Journal of Instruction, 11(2), 281-296

Ismail, N., Wan, Z.W.A., Aida, S.M.Y. and Ahmad,F.M.A. (2014). The Effects of Blended Learning Methods on Educational Achievement and the Development of Online Material in a Curriculum Information Document Online System (CIDOS) for Computer Application Courses. Malaysian Journal of Distance Education. 16(2), 59-82.

Jethro, O. O., Grace, A. M., Thomas, A. K. (2012). E-Learning and its effects on teaching and learning in a global age. International Journal of Academic Research in Business and Social Sciences. 2, p. 203-210.

Kanuka, H., \& Rourke, L. (2014). Using blended learning strategies to address teaching development needs: How does Canada compare? Canadian Journal of Higher Education, 43(3), 19-35. 
Kazu, I. Y. \& Mehmet, D. (2014). Effect of Blended Learning Environment Model on High School Students' Academic Achievement. The Turkish Online Journal of Educational Technology, 13(1)

Kenney, J., \& Newcombe, E. (2011). Adopting a blended learning approach: Challenges encountered and lessons learned in an action research study. Journal of Asynchronous Learning Networks, 15(1), 45-57.

Kintu, M. J., Zhu, C., Kagambe, E. (2017). Blended learning effectiveness: the relationship between student characteristics, design features and outcomes. International Journal of Educational Technology in Higher Education. 14(7).

Krishnan, D. (2015). Effect of Blended Learning Strategy on Learning Science among Secondary School Students. Proceedings : Emerging Computational Media and Science Education, Mumbai : Cinnamonteal Publishing.

Korkmaz. O, \& Karakus U (2009). The impact of blended learning model on student's altitude towards geography course and their critical thinking dispositions and levels. The Turk. Online J.Educ. Technol. 4. 51-63.

Lim, D. H. \& Morris, M. L. (2009). Learner and instructional factors influencing learning outcomes within a blended learning environment. Educational Technology \& Society, 12(4), 282-293.

Lizzio, A., Wilson, K., \& Simons, R. (2002). University students' perceptions of the learning environment and academic outcomes: implications for theory and practice. Studies in Higher Education, 27(1), 27-52.

Maguire, L. L. (2005). Literature review - Faculty participation in online distance education: Barriers and motivators. Online Journal of Distance Learning Administration. Available at: http://www.westga.edu/ distance/ojdla/spring81/maguire81.htm.

Means, B. Toyama, Y., Murphy, R., \& Bakia, M. (2013). The effectiveness of online and blended learning: A meta analysis of the empirical literature. Teachers College. Record, 115(3), 1-47.

Morel, R., Domenjoz, J-C., Lachat, C. and Rossi, C. 2003. From teacher education to professional development for e-learning in an e-society. In C. Dowling and K-W. Lai $(E d s)$. Information and Communication Technology and the Teacher of the Future. Kluwer Academic Publishers, Boston.

Munir. 2009. Pembelajaran Jarak Jauh Berbasis Teknologi Informasi dan Komunikasi. Bandung: Alfabeta.

Nasution, N.E.A., Harahap. F. and Manurung, B. (2016). The Effect of Blended Learning on Student's Critical Thinking Skills in Plant Tissue Culture Course. International Journal of Science and Research (IJSR), 6(11), 1469 - 147 
Nasution, N.E.A., Harahap. F. and Manurung, B. (2017). Rancang Bangun Website Pembelajaran Pada Perguruan Tinggi (Studi Kasus : Mata Kuliah Kultur Jaringan. Prosiding Seminar Nasional III Biologi dan Pembelajarannya, Universitas Negeri Medan, 2017. Pp, 643-656

Obiedat, R, L., Edden, N., Harfoushi, O., Koury, M., Al-Hamarsheh and , AlAssaf, N. (2014). Effect of Blended-Learning on Academic Achievement of Students in the University of Jordan. International Journal of Emerging Technologies in Learning. 9(2).

Osguthorpe R. T. \& Graham, C. R. (2003). Blended Learning Environments Definitions and Directions. The Quarterly Review of Distance Education, 4/3: 227-233.

O'Toole, J. M. \& Absalom, D. J. (2003). The impact of blended learning on student outcomes: Is there room on the horse for two? Journal of Educational Media, 28(2-3), 179-190.

Poon, J. (2013). Blended Learning: An Institutional Approach for Enhancing Students' Learning Experiences. MERLOT Journal of Online Learning and Teaching. Vol 9/2. 271-289.

Raj, R. G. \& Devi, S. N. (2014). Science Process Skills and Achievement in Science Among High School Students. An Internation Peer Reviewed. Scholarly Research Journal for Interdisciplinary Studies. Vol 2(15). 2435 -2443.

Ruseffendi, E. T. (1991). Pengantar kepada membantu guru mengembangkan kompetensinya dalam pengajaran matematika meningkatkan CBSA. Bandung: Tarsito.

Rustaman, A. 2005. Pengembangan Kompetensi (Pengetahuan, keterampilan, Sikap, dan Nilai) Melalui Kegiatan Praktikum Biologi. Penelitian. Jurusan Pendidikan Biologi FPMIPA UPI Bandung.

Saat, R. M. (2004). The acquisition of integrated science process skills in a web-based learning environment. Research in Science \& Technological Education, 22(1), 23-40.

Simpson, M. \& Anderson, B. (2009). Redesigning initial teacher education. In E. Stacey $\&$ P. Gerbic(Eds.), Effective blended learning practices. Evidence-based perspectives in ICT-facilitated education,(pp. 62-78). Hershey PA: Information Science Reference.

Snodin, N. S. (2013). The Effects of blended Learning with a CMS on the Development of Autonomous Learning: A Case Study of Different Degrees of Autonomy Achieved by Individual Learners. Computers \& Education. 61: 209-216.

Sridevi, K. V. (2008). Constructivism in science education. New Delhi: Discovery Publishing House Pvt. Ltd.

Sudjana, N., (2006), Penilaian Hasil Belajar Mengajar, Penerbit PT. Remaja Rosdakarya, Bandung.

Suparno, P. 1997. Filsafat konstruktivime dalam pendidikan. Yogyakarta: Kanisius. 
Sumantri, M., and Permana, J. (2001), Strategi Belajar Mengajar. Bandung : CV Molana

Twigg, C. A. (2003). Improving learning and reducing costs: Lessons learned from Round 1 of the Pew grant program in course redesign. Troy, NY: Center for Academic Transformation.

Tan, S. C., Yeo, A.C.J., Lim, W.Y. (2005). Changing epistemology of science learning through inquiry with computer-supported collaborative learning. Journal of Computers in Mathematics and Science Teaching, 24(4), 367-386.

Wijaya, C. 2012. Pendidikan Remidial. Bandung: Remaja Rosdakarya.

Zou, J. P. (2005). E-Learning new world - Internet and learning. Taipei, Taiwan: Tingmao. 